\title{
Simulating Groundwater Charges for the Moroccan Drâa River Basin
}

\author{
Claudia Heidecke* and Arnim Kuhn \\ Institute for Food and Resource Economics, University of Bonn, \\ Nusßallee 21, 53115 Bonn, Germany
}

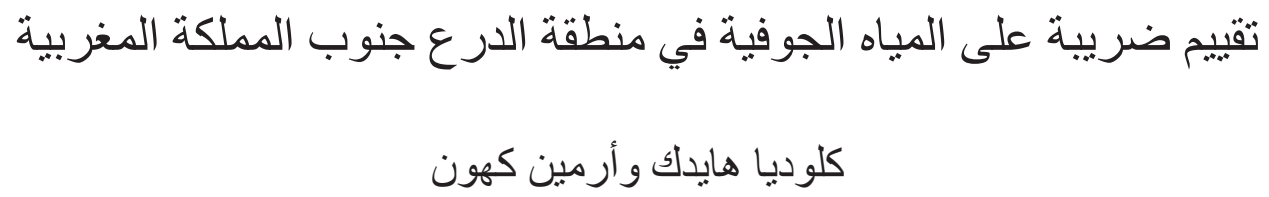

الخلاصة: تعتمد الزر اعة في الو احات الستة في منطقة الدرع جنوب المملكة المغربية على المياه الجوفية. تشنكي المنطقة من جفاف

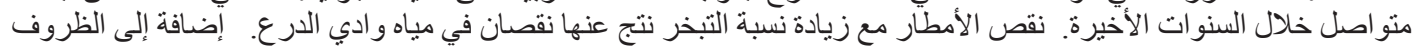

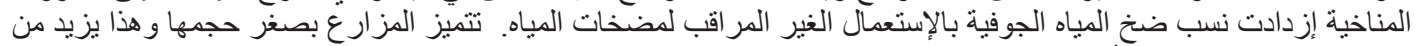

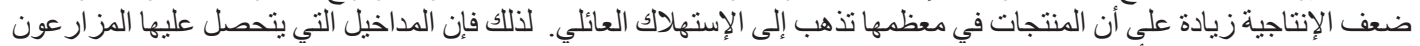

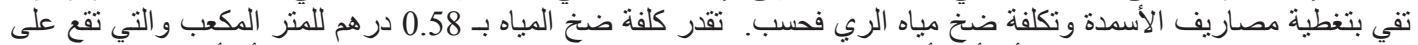

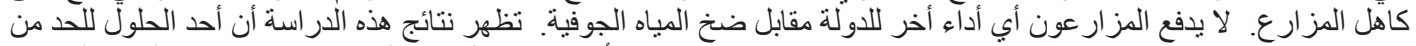

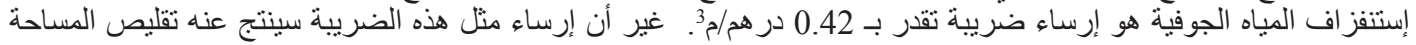
المزرو عة بنسبة 50 بالمائة.

ABSTRACT: Agricultural production in the six oases in the Drâa Region in Southern Morocco is highly dependent on irrigation using mainly traditional irrigation channels or pumps. The basin has been suffering enormously from a continuing drought during recent years. Declining rainfall and high evapotranspiration rates in the semi-arid region lead to lower flow in the Drâa River. Aggravating this situation, farmers increasingly pump groundwater with motor pumps, leading to a rapidly drop in the aquifer. However, agricultural production is economically inefficient and based on subsistence farming. The income a farmer gets by selling a share of his production on the local markets hardly covers the variable costs for fertilizers and irrigation water. Farmers do pay only the pumping cost estimated at $0.58 \mathrm{Dh} / \mathrm{m}^{3}$. To prevent a further drop in the groundwater table, and hence to conserve water resources, the introduction of a water charge is evaluated with the MIVAD River Basin Model (RBM). This shows that imposing a water change of $0.42 \mathrm{Dh} / \mathrm{m}^{3}$ leads to stable groundwater table, but with a drop in cropped area by $50 \%$.

Keywords: Water pricing, subsistence farming, income, groundwater.

\section{Introduction}

Charging farmers for scarce irrigation water use is increasingly regarded as a means of encouraging efficient water allocation (Cornish et al., 2004). In this context, water pricing regimes have been established for most irrigation perimeters in Morocco in order to meet the needs for operation and maintenance of irrigation systems as well as to encourage investments in water-saving irrigation technologies. The Drâa valley is the only river basin where this national strategy has not yet been implemented (Serghini, 2002). But, as a consequence of a continued drought during recent years, the supply of centrally distributed river water has become ever more unreliable, pushing farmers to increasingly rely on groundwater. This has inevitably led to declining groundwater tables

\footnotetext{
* Corresponding author. E-mail: claudia.heidecke@ilr.uni-bonn.de
} 
Table 1. Irrigation rates and O\&M costs for different agricultural regions in Morocco.

\begin{tabular}{lrc}
\hline ORMVA & $\begin{array}{c}\text { Current water } \\
\text { charges } \\
\left(\mathbf{D h} / \mathbf{m}^{\mathbf{3}} \mathbf{)}\right.\end{array}$ & $\begin{array}{c}\text { O\&M Costs } \\
\left(\mathbf{D h} / \mathbf{m}^{\mathbf{3}} \mathbf{)}\right.\end{array}$ \\
\hline Moulouya & $0.19-0.34$ & $0.22-0.57$ \\
Haouz & 0.17 & $0.14-0.22$ \\
Loukkos & 0.40 & $0.46-0.66$ \\
Souss_Massa & $0.38-0.50$ & $0.25-0.89$ \\
Tadia & 0.17 & $0.09-0.14$ \\
Doukkala & $0.18-0.25$ & $0.12-0.23$ \\
Doukkala & $0.34-0.41$ & $0.33-0.37$ \\
Gharb & $0.19-0.40$ & $0.24-0.44$ \\
\hline
\end{tabular}

Source: Tsur et al. (2004)

Note: Irrigation costs for Large Scale Irrigation Systems

Rate of exchange to US\$: 1Moroccan Dirham 0.12 US\$ (April 2006).

and their salinization. This paper aims at identifying a groundwater charge sufficiently high to substantially curb the drop of groundwater tables. For this purpose, the effects of pumping costs in the current situation as well as additional groundwater water charges on farm income and sustainable water availability in the region are simulated using an integrated River Basin Model (RBM). Empirical information on water costs and cropping profitability were obtained from a farm survey.

The paper is organised as follows. First, a brief overview of water pricing in other watersheds in Morocco is provided. Then the Drâa River Basin water management policies are described. After a description of the research methodology the alternative water charges for agriculture in the Drâa valley are compared, followed by conclusions. The results presented are based on interdisciplinary research carried out by the IMPETUS project (www.impetus.uni-koeln.de) which aims at an integrated assessment of the water cycle as well as water management alternatives for the region.

\section{Irrigation and Water Pricing in Morocco}

In 1969 the Ministry of Rural Development passed the Agricultural Investment Code (CIA) including a framework for the introduction of water prices for irrigation water in Morocco. Except for the Drâa basin, all other watersheds in Morocco have adopted water pricing schemes in recent years. Investment costs of irrigation water are shared between the general budget $(60 \%$ and the beneficiaries $(40 \%)$, i.e. the farmers who

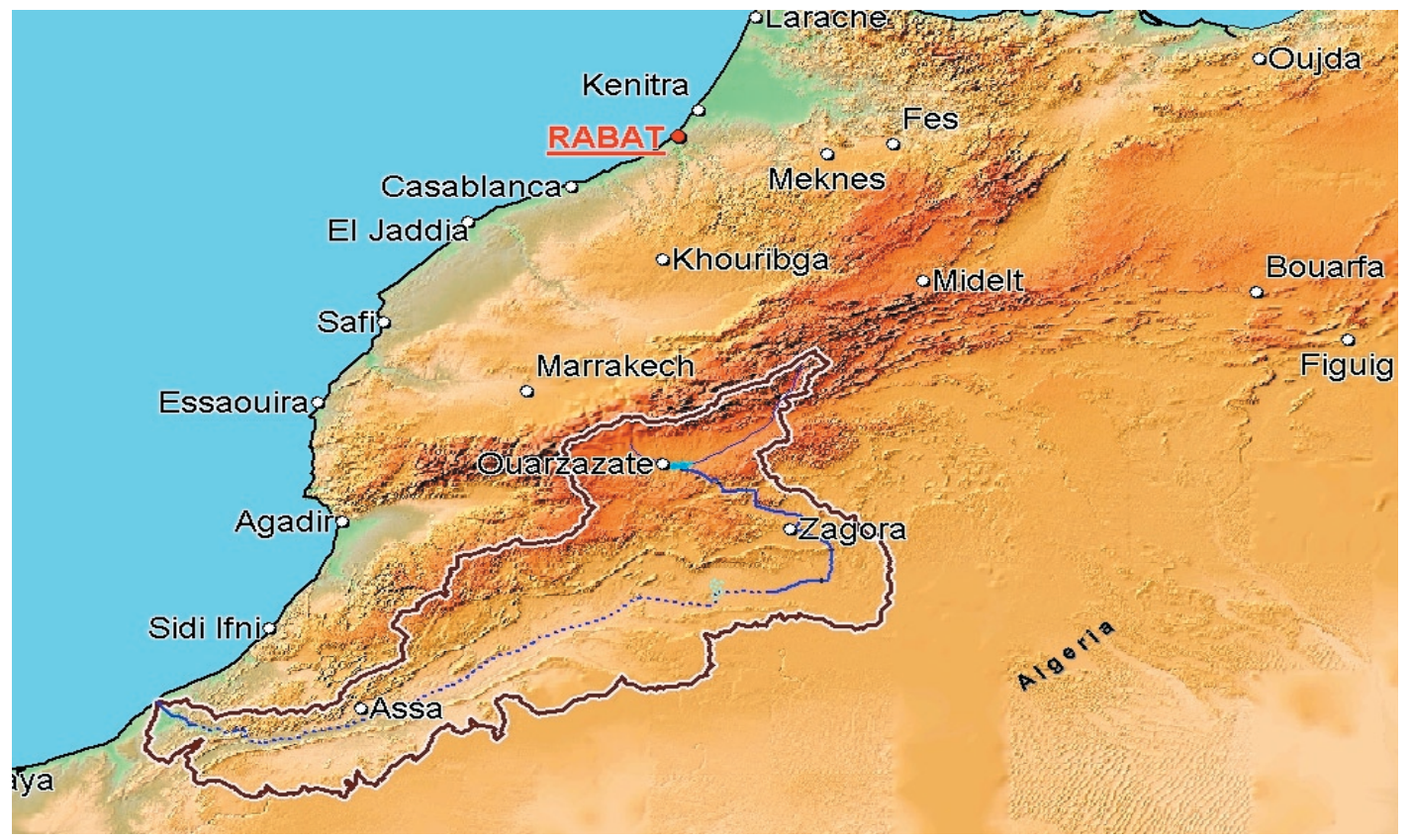

Figure 1. The Drâa catchment area.

Source: www. impetus.uni-koeln.de 
are organised in newly established water user groups. The CIA determines the water charges in order to recover all costs of operation and maintenance (O\&M) as well as depreciation. Table 1 shows the level of water charges in the different watersheds in Morocco.

On top of the volumetric water charges, farmers with more than five hectares of land are obliged to pay a fixed charge of 1500 Dirham per hectare and year. However, $80 \%$ of Moroccan farmers are not relevant to this category. Altogether the Moroccan pricing system has contributed to the notorious underfinancing of irrigation schemes (Serghini, 2003). It can be seen that in most cases actual water prices are lower than needed to recover O\&M (Tsur et al., 2004). Moreover, it is an open question whether the design and levels of the water charges are sufficient to ensure sustainable use of surface and groundwater resources by farmers.

\section{Study Area: The Drâa River Basin}

The Drâa river basin (Fig. 1) is one of Morocco's smaller river basins, located close to the Algerian border in the south-eastern part of the country. Its location between the High Atlas Mountains and the Saharan desert is characterized by low rainfall, ranging from about 54 to $106 \mathrm{~mm}$ per year. During recent years droughts have seriously afflicted the region. Along the Drâa valley there is a belt of six oases (Fig. 2) characterised by the cultivation of palm trees, cereals, different kinds of vegetables, and alfalfa and barley for animal forage. Most farms are of small size and are basically subsistence farms (Ouhajou, 1996). The continuing drought has lead to a decrease in farm incomes with the result that young men migrate to the large Moroccan cities or to foreign countries. Numerous families in the oases heavily rely upon the remittances from these emigrated relatives for support.

In 1972 a large water reservoir was built near the provincial capital Ouarzazate, gathering the river inflows from the mountainous areas (Fig. 2). Since then, surface water distribution has been managed in a centralized manner where water is released periodically from the reservoir. Beyond its function as a buffer against shorter droughts and the production of hydropower, another purpose for the reservoir was

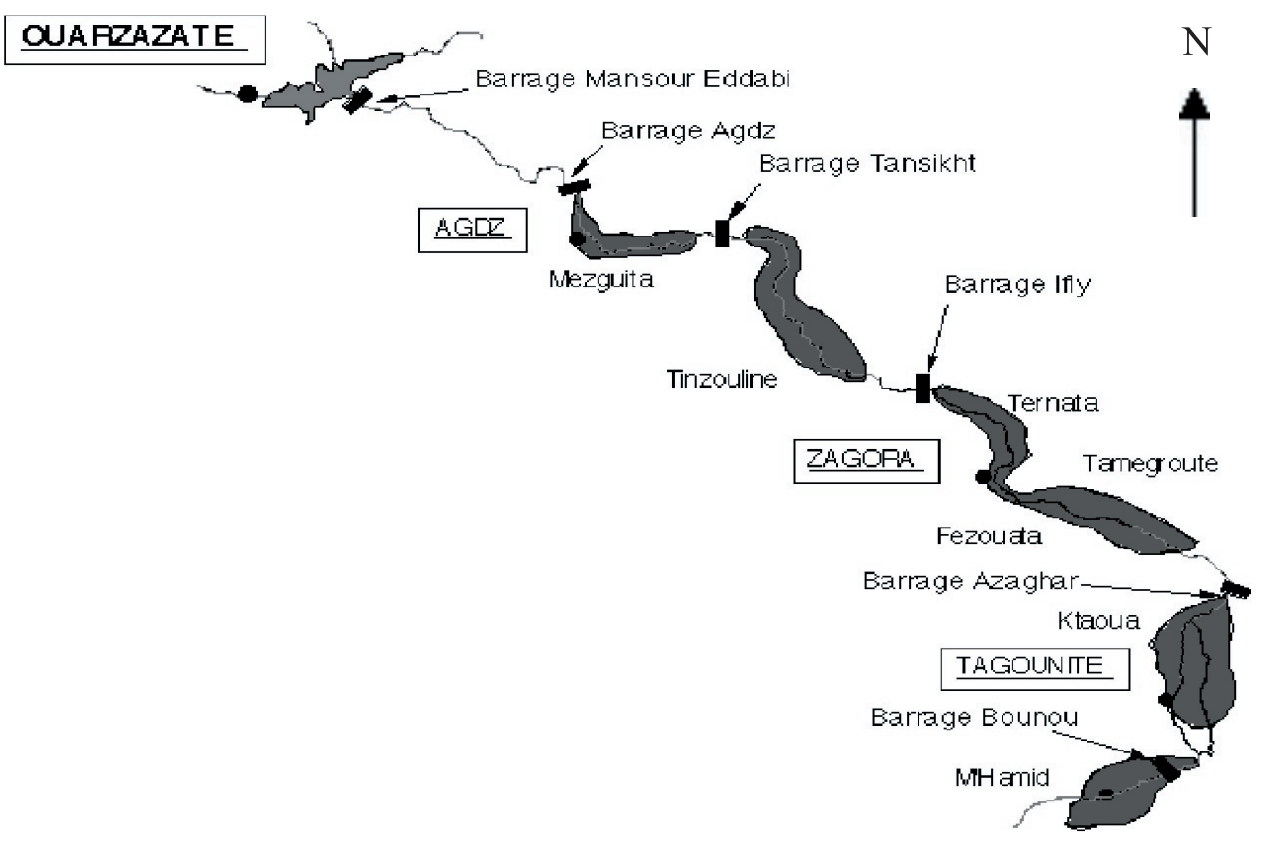

Figure 2. Belt of the six oases included in the survey. 
Table 2. Gross margins and production costs for wheat and alfalfa in the Drâa Basin.

\begin{tabular}{lrr}
\hline & Wheat & Alfalfa \\
\hline Yields (kg/ha) & 1912 & 735 \\
Price per kg (Dh) & 4 & 2 \\
Total irrigation cost (Dh/ha) & 762 & 540 \\
Machinery cost (Dh/ha) & 878 & 647 \\
Cost for seeds (Dh/ha) & 679 & 581 \\
Fertilizer cost (Dh/ha) & 1037 & 275 \\
Total variable costs (Dh/ha) & 3356 & 2043 \\
Gross margin per ha & 4292 & -573 \\
\hline
\end{tabular}

Source: Farm Survey, 2005 and own calculations

Note: Labor costs have not been taken into account. Moreover, it is assumed that irrigation costs are all variable costs (predominantly fuel) as farmers usually do not take the depreciation of motor pumps or other irrigation technologies into account.

Average gross margins are not weighted for individual farm sizes.

Rate of exchange to US\$: 1 Moroccan Dirham 0.12 US\$ (April 2006).

to distribute water more evenly across the oases from north to south, giving the southern oases the chance to use water for irrigation first, while the northern oases had the advantage that their groundwater storage was recharged (Ouhajou, 1996). Nevertheless, since 1990 river basins south of the Atlas Mountains were characterised by negative hydrologic balances and these are likely to worsen further until 2020 (Debbarh, 2002).

Until the beginning of the drought of the mid nineties this centralized water management helped to stabilize irrigation water supply. But due to declining rainfall and high evapotransipration rates, water releases from the reservoir are becoming more and more scant and irregular, and are mainly supposed to fill up groundwater levels of the aquifers below the oases. Consequently, extraction of groundwater has increased considerably in the form of digging private wells and installing motor pumps. Nowadays an average farmer owns two wells with motor pumps which run almost 12 hours per day during the cropping season, according to survey data. As a result the groundwater table has declined and salinization has increased during recent years (Fig. 3).
To evaluate the impact of a water pricing scheme it is necessary to look at the farmer's income to see whether they are able to cope with the increasing costs, in a short as well as in a long-term perspective. Table 2 illustrates gross margins for alfalfa and wheat with local prices and total production costs per hectare.

Gross margins for date palms are difficult to determine since variable costs were difficult to identify. Gross profits are assumed to amount to approximately 200 Dirham per tree according to the survey results. Taking into account that farmers cultivate for self-consumption, the low level of the gross margins appears to be realistic, resulting in low remuneration for family work, but not leading to 'visible' monetary losses. However, with increased water costs, the negative gap widens. Many farmers, particularly those who do not cultivate date palms as cash crops, will find it difficult to pay for additional water charges.

As farmers will not stop the over-exploitation of groundwater until the aquifers are either depleted or salinized to an extent which makes water use for irrigation impossible, charging prices for groundwater use might be an option to curb the depletion of the common resource. However, as this price would have to be paid for from the already narrow agricultural profits, it is unlikely that water prices would leave the current size structure and performance of farms unchanged.

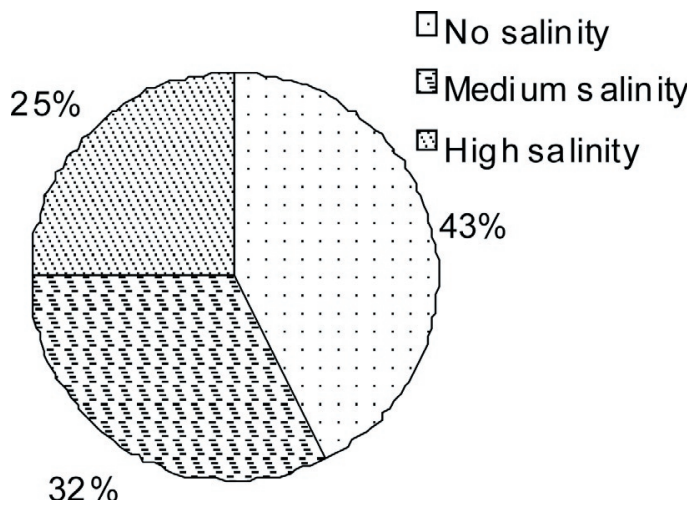

Figure 3. Problem of salinization in the Drâa region as perceived by farmers.

Source: Own Farm Survey, October 2005

Note: Data according to farmers own assumption of salinization; measurements of electronic conductivity have been conducted in some cases for verification. 


\section{Methodology: the MIVAD model}

The following section is investigating two questions: which price level would preserve groundwater resources and thus enable oasis farming in the longer perspective, and which changes regarding the extent cropping activities would this price level require? Both questions can be answered by simulating alternative water costs with the MIVAD model (Modèle Integrée du Vallée du Drâa), an integrated hydro-agro-economic river basin model (RBM, see also Rosegrant et al., 2000) for the Drâa Region. MIVAD is an economic optimization model which simultaneously maximizes agricultural and hydropower generation profits as well as consumers' utility from drinking water consumption (equation 1).

$$
\operatorname{Max}(\mathrm{obj})=\left\{\begin{array}{c}
\sum_{\text {oæes }} \text { Profit (irrigation in agriculture) } \\
\sum_{\text {muxicip }} \text { Utility (drinking water use) } \\
\sum_{\text {powerst }} \text { Profit (hydropower generation) }
\end{array}\right\}
$$

The objective function of MIVAD is subject to a variety of constraints, represented by bounds and balance equations related to hydrology (river, groundwater and reservoir balances), agronomy (crop yield response, area and cropping mixes) and general technological aspects (hydropower, pumping by public and private agents), all of which have to be taken into account. Agricultural production is represented as an LP exercise involving six stylised oasis farms. The response of crop yields to water stress is modelled by a modified Penman-Monteith function (Allen et al., 1998). Spatial relationships are represented in a node network representing different in- and outflows, reservoirs and water demand sites. Water distribution is modelled between the nodes. The network of the Drâa river basin actually starts with the inflow node that defines the reservoir inflow exogenously for each month.

The model is run over several years as a recursivedynamic model, with each year divided into twelve months, which are solved simultaneously. MIVAD is written and executed using GAMS (General Algebraic Modelling System). Data used in the model have been mainly obtained from public official data sources and from the IMPETUS database. In addition, data from an agro-economic survey covering 60 farmers with different resource endowments (conducted in autumn 2005 in the six oases along the Drâa river), were used to round off the database of the model in the near future. Currently they contribute to the validation of the model results.

\section{Simulating Alternative Groundwater Charges}

Three water cost scenarios are simulated against a common background, a sequence of five years with low precipitation in the High Atlas and thus low water flows into the Mansour Edahbi reservoir. The magnitude of inflows was chosen as the average of the five driest years during the recent twenty years. It is further assumed that the reservoir is already running at its minimum fill rate of $30 \%$.

The next important step is to identify appropriate groundwater pumping costs and additional water charges. Costs for pumping water are fairly high in the Drâa Region compared to the free surface water from the Drâa River. Farmers need up to one and a half litres of diesel fuel per hour, depending on the condition of the motor pump. Furthermore, lubricant oil needs to be changed regularly to ensure the reliability of the pump. Operation and maintenance costs of pumps account for 500 Moroccan Dirham on average per pump per year. On average, farmers in the Drâa Region manage to pump approximately 14 to 22 cubic meter of water per hour, depending on the type of motor pump and the amount of water in the well (as measured by Klose and Reichert, 2006). This amounts to variable pumping costs of 0.58 Moroccan Dirham per cubic meter of irrigation water, depending on the capacity and efficiency of the motor pump as well as local petrol prices. The fixed costs of groundwater pumping (mainly the maintenance and replacement of pumps) are more difficult to measure. Moreover, it is not certain whether fixed costs are well known to the farmers and if these influence their decisions regarding groundwater use. The farm survey results indicate that the use of inputs is often not oriented at profitability only, but also at keeping up a certain production level for subsistence. This is possible because the increasing share of remittances in local incomes enables an implicit subsidisation of the households' farming activities. In general, remittances are an important contribution to Moroccan household incomes (Sorensen, 2004).

It is likely that farmers take variable, instead of full pumping costs into account when deciding on 


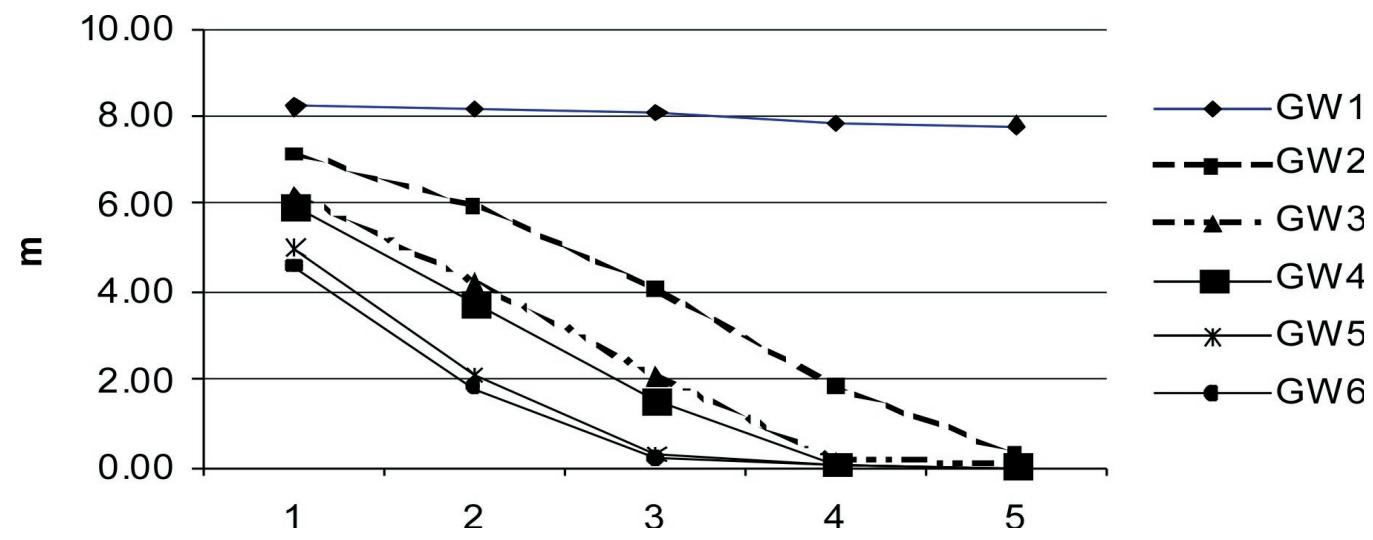

Years

Figure 4. Simulated groundwater tables in meters at water costs of 0.58 Dirham $/ \mathrm{m}^{3}$

groundwater use. Therefore, scenarios for pumping costs of 0.58 Dirham (the variable pumping costs according to the survey data) as well as costs of 1.00 Dirham per cubic metre, have been simulated. The aim is to increase the economic scarcity of water, such that groundwater use becomes more sustainable within a five-year period of drought. Groundwater pumping is significantly lower at total pumping costs of 1.00 Dirham per cubic meter. However, this means that less than half of the available land resources would be cropped, and that agricultural profits would contribute less to household incomes (Table 3). Water use has become much more efficient, which is reflected in higher average shadow water prices, i.e. the marginal value of water. Moreover, the agricultural profit produced by $1 \mathrm{~m}^{3}$ of irrigation water - the average value of water - increases from 0.36 to 0.50 Dirham.

Figures 4 and 5 show the development of the groundwater levels in the different aquifers belonging to the oases. With the actual pumping costs of 0.58 $\mathrm{Dh} / \mathrm{m}^{3}$, a depletion of groundwater resources occurs within five years for all aquifers except one, which is big enough to supply enough water for the farmers. By contrast, a water charge of $0.42 \mathrm{Dh}_{\text {per }} \mathrm{m}^{3}$ leads to stable groundwater levels since in such a case the total cost to the farmer becomes $1 \mathrm{Dh}$. However, this water charge would require the installation of water meters on each of the wells, and an administrative mechanism to monitor water use and the collection of charges.

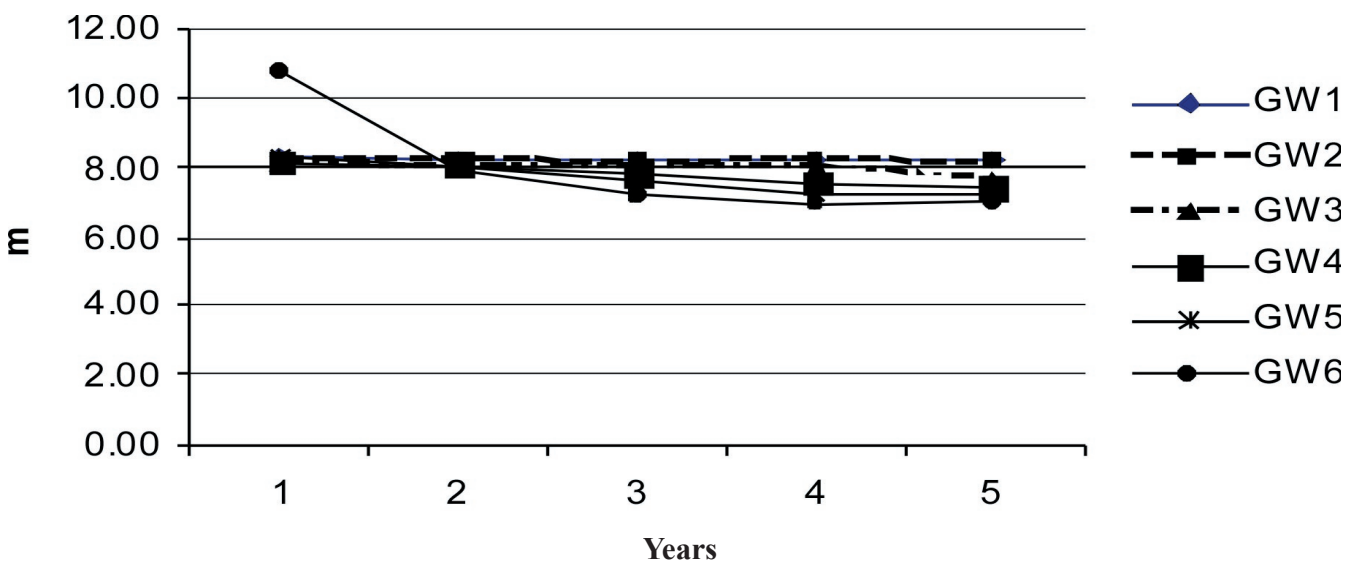

Figure 5. Simulated groundwater tables in meters at water costs of 1.00 Dirham $/ \mathrm{m}^{3}$ 


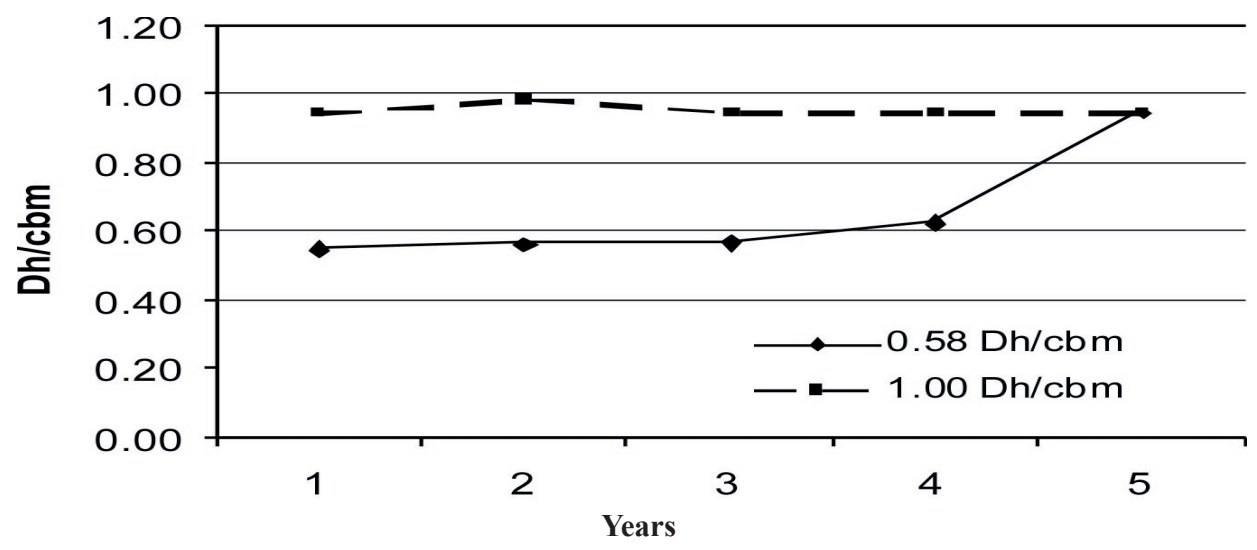

Figure 6. Development of shadow prices under different water costs over the 5-year simulation period.

Figure 6 depicts the increase of shadow prices over a period of five years, depending on costs for irrigation water. Due to the increasing irrigation costs, water resources become scarcer economically. Farmers pump less water due to an increase in costs and change their cropping patterns to achieve greater water efficiency. This process is reflected by an increase in the marginal value of water, the so called agricultural water shadow price.

With pumping costs of 1 Dirham per cubic meter the agricultural water shadow price remains most stable with values of under one Dirham. For pumping costs of 0.58 Dirham the marginal value of water is nearly as high as the direct pumping costs that farmers pay already at the moment. Shadow prices increase in the course the simulation period, reflecting the depletion of groundwater resources as shown in Figure 4.

\section{Conclusions}

Although the Agricultural Investment Code has not yet been implemented in the Drâa River Basin, this does not mean that the use of irrigation water has been free of costs for the farmers in this region during recent last years. The survey shows that, on the one hand, direct costs for groundwater pumping exist and are even higher than prices farmers are charged in other basins. On the other hand, if only variable costs at these levels are taken into account in the farmers' decision-making, they are unlikely to work as an effective constraint to excessive groundwater pumping. The simulation results, which only take variable costs into account, display a quick depletion of groundwater resources, which matches quite closely the developments of recent years in the Drâa valley. This means that, at least from a perspective solely oriented at resource sustainability, it would be justified to complement these costs with a water charge. According to the simulation results, it can be shown that groundwater tables can be stabilised by introducing charges. With an additional charge of 0.42 Dirham, the current (variable) costs of 0.58 Dirham would reach a total cost of 1.00 Dirham per cubic meter.

This 'sustainable' water charge, however, would be four to five times higher than the water prices charged in the other irrigation perimeters in Morocco. That indicates that the question of charging for irrigation water needs to be treated with considerable care as farmers already operate on the edge of subsistence. In a situation where huge families have to be fed, drought conditions squeeze farm incomes such that the migration of the young men is often the only way to ensure the livelihood of those family members who stay in the Drâa valley. Introducing water charges without considering the depressed economic situation of farms would put an end to most of the small farm entities in the region. Water pricing should therefore not be introduced as an isolated solution, but should rather be embedded in a broader approach towards rural development in the region, aimed at both poverty reduction and resource conservation.

\section{Acknowledgement}

The research carried out in this paper has been funded by the interdisciplinary project IMPETUS (Integrated Management Project for the Efficient Use of Water Resources in West Africa) carried 
out by the universities of Cologne and Bonn (see: www.impetus.uni-koeln.de). The authors are grateful to Ridouane Oumouch and Hamd El Mansouri for their great support in Morocco. Helpful input has also been received from the other IMPETUS colleagues.

\section{References}

Allen, R. G., L.S. Pereira, D. Raes and M. Smith. 1998. Crop evapotranspiration- Guidelines for computing crop water requirements. FAO Irrigation and Drainage Paper No. 56, pp. 65-86.

Debbarh, A. 2002. L'irrigation au Maroc: un choix stratégique pour le développement agricole et la sécurité alimentaire. In : Agridoc-revue thématique $4: 10-20-21$.

Cornish, G., B. Bosworth, C. Perry and J. Burke. 2004. Water charging in irrigated agriculture - An analysis of international experience. FAO Water Reports No. 28. Rome, pp.5.

Klose, S. and B. Reichert. 2006. Groundwater management in the middle Drâa-River basin (South-Morocco). Paper Presented at the ISCO Conference, 14-19 th $^{\text {May } 2006 . ~ M a r r a k e c h . ~}$ www.tucson.ars.ag.gov/isco
Ouhajou, L. 1996. Espace Hydraulique et Société au Maroc- Cas des Système d'irrigation dans la vallée du Drâa. Faculté des Lettres et des Sciences Humaines. Thèse et Mémoire. Agadir, pp. 74-76.

Rosegrant, M.W., C. Ringler, D.C. McKinney, X. Cai, A. Keller and G. Donoso. 2000. Integrated economic-hydrologic water modelling at the basin scale: the Maipo river basin, EPTD Discussion Paper No. 63. IFPRI. Washington, D.C.

Serghini, M. 2002. L'eau, ressource de l'avenir. In: New Mediterranean 2:60-64.

Serghini, M. 2003. La tarification des services de l'eau au Maroc. In: New Medit 1:5-13.

Sorensen, N.N. 2004. Migrant remittances as a development tool: The case of Morocco. Working Paper Series No. 2. International Organization of Migration, pp.5.

Tsur, Y., T. Roe, R. Doukkali and A. Dinar. 2004. A microeconomic analysis of pricing in Morocco, China, Mexico South Africa and Turkey. In: Pricing Irrigation Water- Principles and Cases from Developing Countries. Resources for the Future. Washington D.C. pp. 87-89. 